\title{
Use of Soybean Meal as a Substitute for Fish Meal in a Newly Developed Soft-Dry Pellet for Yellowtail
}

\author{
Voranop Viyakarn, ${ }^{* 1}$ Takeshi Watanabe, ${ }^{* 1}$ Hideo Aoki, ${ }^{* 2}$ Heizo Tsuda, ${ }^{* 2}$ \\ Hiroshi Sakamoto, ${ }^{* 3}$ Nobuaki Okamoto, ${ }^{* 4}$ Naomichi Iso, ${ }^{* 5}$ \\ Shuichi Satoh, ${ }^{* 1}$ and Toshio Takeuchi ${ }^{* 1}$ \\ (Received May 26 1992)
}

\begin{abstract}
The availability of defatted soybean meal (SBM) as a substitute for fish meal (FM) in a newly developed soft-dry pellet (SDP) was evaluated by feeding SDP containing 0-50\% SBM to both juvenile and adult yellowtail.

Palatability or acceptability of the experimental SDP was not influenced by the inclusion of SBM up to $50 \%$. Growth and feed gain ratio were highest in both sizes of fish fed on the control FM diet but decreased corresponding to the elevation of SBM levels. This might be due to the reduced levels of protein and energy in the SBM diets resulting from the difference in protein and lipid contents between FM and SBM, as the diets were not iso-nitrogenous and iso-caloric. This was also supported by the result that the weight gain per digestible energy or protein intake did not differ greatly among the experimental groups. A diet with $25 \% \mathrm{SBM}$ and $15 \%$ corn gluten meal (CGM) showed better feed performances than the $40 \%$ SBM diet, suggesting the availability of CGM as a protein source in combination with SBM.

These results together with hemochemical assessments and rheological properties have shown that SBM can be included as a protein source up to $30 \%$ in place of FM in SDP for yellowtail without any adverse effects.
\end{abstract}

A recent drop in the catch of feed-grade fish for aquaculture and an increased awareness of environment-friendly farming principles have fueled demand for less-polluting, least-cost dry diets in japan. The increased cost of fish meal, the principal component of practical diets, has prompted research in suitable alternative protein sources.

A previous experiment ${ }^{13}$ has demonstrated that defatted soybean meal (SBM) could be included as a protein source up to $30 \%$ instead of fish meal (substitution of about $55 \%$ fish meal) in a newly developed soft-dry pellet for both juyenile and adult yellowtail without any ill effects. Nevertheless, elevation of a protein or an energy level was found necessary to obtain growth and feed efficiency comparable to the control fish meal diet, due to the difference in proximate composition of SBM and fish meal. Palatability and acceptability in terms of total feed intake were not influenced by the inclusion of $30 \%$ SBM for either juvenile and adult yellowtail. The feed intake was rather high in fish receiving the SBM-containing diets, probably due to the lower protein and energy contents of the SBM diets. The high palatability of the SBM diets could be attributed to the soft-dry texture of the highly acceptable twin extruder manufactured pellets.

As an adjunct to the previous experiment, it was decided to investigate the effects of increased inclusion of SBM up to $50 \%$ in similarly crafted soft-dry pellets made available to juvenile and adult yellowtail.

*1 Laboratory of Fish Nutrition, Tokyo University of Fisheries, Konan, Minato, Tokyo 108 Japan (V. Viyakarn, 源遍 武, 佐藤秀一, 竹内俊郎：東京水莝大学資源肖成学科).

*2 Owase Branch, Mie Prefectural Institute of Fisheries, Ohaza Tenmanura, Owase, Mie 519-36, Japan

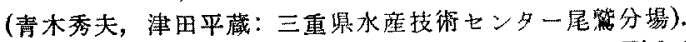

*3 Laboratory of Fish Feed Development, Sakamoto Fish Feed Co. Ltd,, Matsugishi, Choshi, Chiba 288, Japan (坂本浩志: 坂本飼料株式会社研究開発宝).

*4 Laboratory of Fish Physiology, Tokyo University of Fisheries, Konan, Minato, Tokyo 108 Japan (㜀本 信明: 東京水大学筫源育成学科).

* Laboratory of Food Chemistry, Tokyo University of Fisheries, Konan, Minato, Tokyo 108, Japan (磯 直道: 果京水産大学食品生原学科). 


\section{Materials and Methods}

\section{Feeding Conditions}

Feeding experiments were conducted with juvenile yellowtail Seriola quinqueradiata retained in floating net cages located in an inlet near the Mie Prefectural Institute of Aquaculature (Expt. I) and in the aquarium of the Seibu Iojima Sea Ranching Co. (Expt. II).

Expt. I: Adult yellowtail weighing $345-365 \mathrm{~g}$

Table 1. Composition of the experimental diets with or without soybean meal or corn gluten meal for the juvenile (Expt. II) and adult yellowtail (Expt. I)

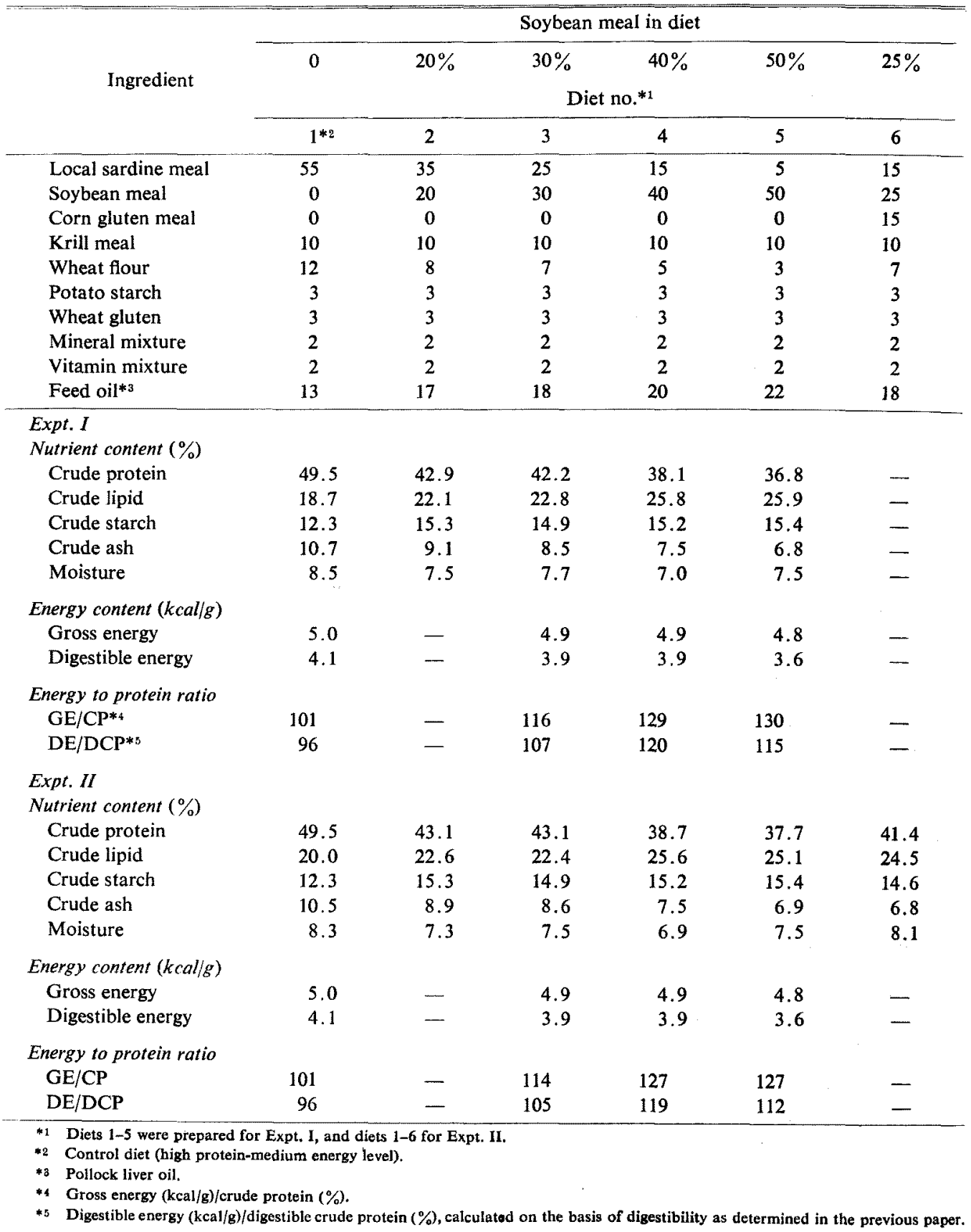


were used for the feeding experiment. Initially these fish were collected as wild caught fry in June and fed on a commercial soft-dry pellet (Sakamoto Fish Feed Co.) until September. They were then divided into five groups of 300 fish each, kept in net cages $(3 \times 3 \times 3 \mathrm{~m})$ with net covers, and fed on the experimental diets containing $0-50 \%$ SBM from September 5th to December 16th (70 days feeding). Fish were fed 6 days a week, once in the morning, at a feeding rate of $2.6-2.9 \%$ of body weight. Cor- responding to the growth of the fish, the number of fish per cage was gauged every month during the determination of total body weight, and numbered 243-245 fish from October 11th to November 12th and 200 fish from November 13th to December 16th. The initial water temperature of $26.1^{\circ} \mathrm{C}$ dropped to $20.6^{\circ} \mathrm{C}$ in the final phases.

At the end of feeding five fish were taken from each lot for analysis of protein and lipid contents of muscle. The analytical procedures for prox-

Table 2. Fatty acid composition of total lipids in diets with soybean meal (SBM)

\begin{tabular}{|c|c|c|c|c|c|c|}
\hline & & & & & & (Area \% \\
\hline \multirow{2}{*}{ Fatty acid } & \multicolumn{6}{|c|}{ SBM in diet } \\
\hline & $0 \%$ & $20 \%$ & $30 \%$ & $40 \%$ & $50 \%$ & $25 \% *$ \\
\hline $14: 0$ & 5.3 & 5.3 & 5.2 & 5.3 & 5.0 & 5.7 \\
\hline $14: 1$ & 0.1 & 0.1 & 0.1 & 0.1 & 0.1 & 0.1 \\
\hline $15: 0$ & 0.3 & 0.3 & 0.3 & 0.3 & 0.3 & 0.3 \\
\hline $16: 0$ & 17.2 & 16.4 & 16.2 & 15.7 & 15.2 & 15.1 \\
\hline $16: \ln -7$ & 6.8 & 7.5 & 7.6 & 7.6 & 7.7 & 7.5 \\
\hline $17: 0$ & 0.8 & 0.8 & 0.9 & 0.9 & 0.9 & 0.9 \\
\hline $16: 3 n-6$ & 0.5 & 0.5 & 0.5 & 0.5 & 0.5 & 0.5 \\
\hline $16: 3 n-3$ & 1.1 & 1.1 & 1.0 & 1.1 & 1.0 & 1.1 \\
\hline $18: 0$ & 3.2 & 2.9 & 2.9 & 2.7 & 2.7 & 2.7 \\
\hline $18: \ln -9$ & 12.4 & 13.4 & 13.8 & 13.4 & 14.0 & 13.8 \\
\hline $18: \ln -7$ & 4.2 & 4.4 & 4.6 & 4.5 & 4.5 & 4.5 \\
\hline $18: \ln -5$ & 0.2 & 0.2 & 0.2 & 0.3 & 0.3 & 0.3 \\
\hline $18: 2 n-6$ & 4.1 & 3.9 & 4.0 & 3.7 & 4.0 & 4.4 \\
\hline $18: 3 n-6$ & 0.2 & 0.2 & 0.2 & 0.2 & 0.2 & 0.2 \\
\hline $18: 3 n-3$ & 1.0 & 1.0 & 1.1 & 1.0 & 1.1 & 1.0 \\
\hline $18: 4 n-3$ & 2.0 & 2.0 & 1.9 & 1.9 & 1.8 & 1.9 \\
\hline $18: 4 n-1$ & 0.2 & 0.2 & 0.2 & 0.2 & 0.2 & 0.2 \\
\hline $20: 0$ & 0.1 & 0.2 & 0.2 & 0.1 & 0.1 & 0.1 \\
\hline $20: \ln -11$ & 3.5 & 3.3 & 3.8 & 4.0 & 4.2 & 4.0 \\
\hline $20: 1 n-9$ & 1.9 & 2.1 & 2.2 & 2.2 & 2.4 & 2.2 \\
\hline $20: 1 \mathrm{n}-7$ & 0.1 & 0.1 & 0.2 & 0.1 & 0.2 & 0.2 \\
\hline $20: 2 n-9$ & 0.1 & 0.2 & 0.1 & 0.1 & 0.1 & 0.1 \\
\hline $20: 2 n-6$ & 0.1 & 0.1 & 0.2 & 0.2 & 0.2 & 0.2 \\
\hline $20: 3 n-6$ & 0.1 & 0.1 & 0.1 & 0.1 & 0.1 & 0.1 \\
\hline $20: 4 n-6$ & 0.9 & 0.8 & 0.7 & 0.7 & 0.7 & 0.7 \\
\hline $20: 3 n-3$ & 0.1 & 0.1 & 0.1 & 0.1 & 0.1 & 0.1 \\
\hline $20: 4 n-3$ & 0.6 & 0.5 & 0.5 & 0.5 & 0.5 & 0.5 \\
\hline $20: 5 n-3$ & 13.5 & 13.3 & 12.8 & 13.1 & 12.8 & 13.0 \\
\hline $22: \ln -(13+11)$ & 3.3 & 3.8 & 4.1 & 5.2 & 5.6 & 5.2 \\
\hline $22: \ln -9$ & 0.2 & 0.3 & 0.3 & 0.8 & 0.9 & 0.8 \\
\hline $22: 1 \mathrm{n}-7$ & 0.1 & 0.1 & 0.1 & 0.1 & 0.1 & 0.1 \\
\hline $22: 4 n-6$ & 0.1 & 0.1 & 0.1 & 0.2 & 0.1 & 0.1 \\
\hline $22: 5 n-6$ & 0.2 & 0.2 & 0.2 & tr. & tr. & 0.1 \\
\hline $22: 5 n-3$ & 1.4 & 1.3 & 1.3 & 1.3 & 1.2 & 1.3 \\
\hline $22: 6 n-3$ & 9.9 & 8.4 & 8.0 & 7.4 & 7.0 & 7.3 \\
\hline $\bar{\Sigma}$ Monoene & 32.8 & $35 . \overline{8}$ & 37.1 & 38.3 & 39.8 & 38.9 \\
\hline$\Sigma n-6$ & 6.1 & 5.8 & 5.8 & 5.4 & 6.1 & 5.6 \\
\hline$\sum \mathrm{n}-3$ & 29.5 & 27.8 & 26.8 & 26.5 & 26.2 & 25.6 \\
\hline$\Sigma$ n-3 HUFA & 25.4 & 23.7 & 22.7 & 22.4 & 22.2 & 21.6 \\
\hline
\end{tabular}

* The diet used in Expt. I. 
imate composition were those described previously. ${ }^{2)}$

Expt. II: About one thousand wild juvenile yellowtail weighing $13.4 \mathrm{~g}$ in June were stocked into a floating net cage $(3.5 \times 3.5 \times 5 \mathrm{~m})$ and preliminarily fed a commercial soft-dry pellet (Sakamoto Fish Feed Co.) for about 2 weeks. They were then divided into 25 fish each $(39.0 \mathrm{~g}$ on average), kept in $500 \mathrm{l}$ polycarbonate tanks (Artemia incubation tank) in a land-based aquarium and fed on experimental diets which were the same as those in Expt. I, but which had been crushed and sieved to a suitable size for the experimental fish. The period of feeding was 36 days, and fish were fed twice a day (08:30 and 16:30), each time at a level of $3.0-4.0 \%$ of body weight. Filtered sea water was supplied to each tank at an exchange rate of 14-16 times per day. The water tem- perature was $24.2-25.1^{\circ} \mathrm{C}$ during the feeding trial. The bottom of the feeding tank was cleaned once a day in the evening (18:00). At the end of the feeding term, five fish were taken from each lot for proximate analysis on muscle and liver by standard procedures adopted previously.?

\section{Experimental Diets}

The composition of the experimental diets and their proximate composition are shown in Table 1. A control diet (diet 1) with $55 \%$ fish meal as a main protein source was essentially the same as that used in the former experiment, but was formulated to be a medium energy diet. Diets 2 to 5 were designed to contain $20,30,40$, and $50 \%$ SBM, respectively, by replacing the corresponding level of fish meal in the control diet to examine the effect of dietary SBM levels on palatability and feed performances in yel-

Table 3. Results of adult yellowtail fed on soft-dry pellets containing different levels of soybean meal (SBM) in $3 \times 3 \times 3$ m net cages (Expt. I)

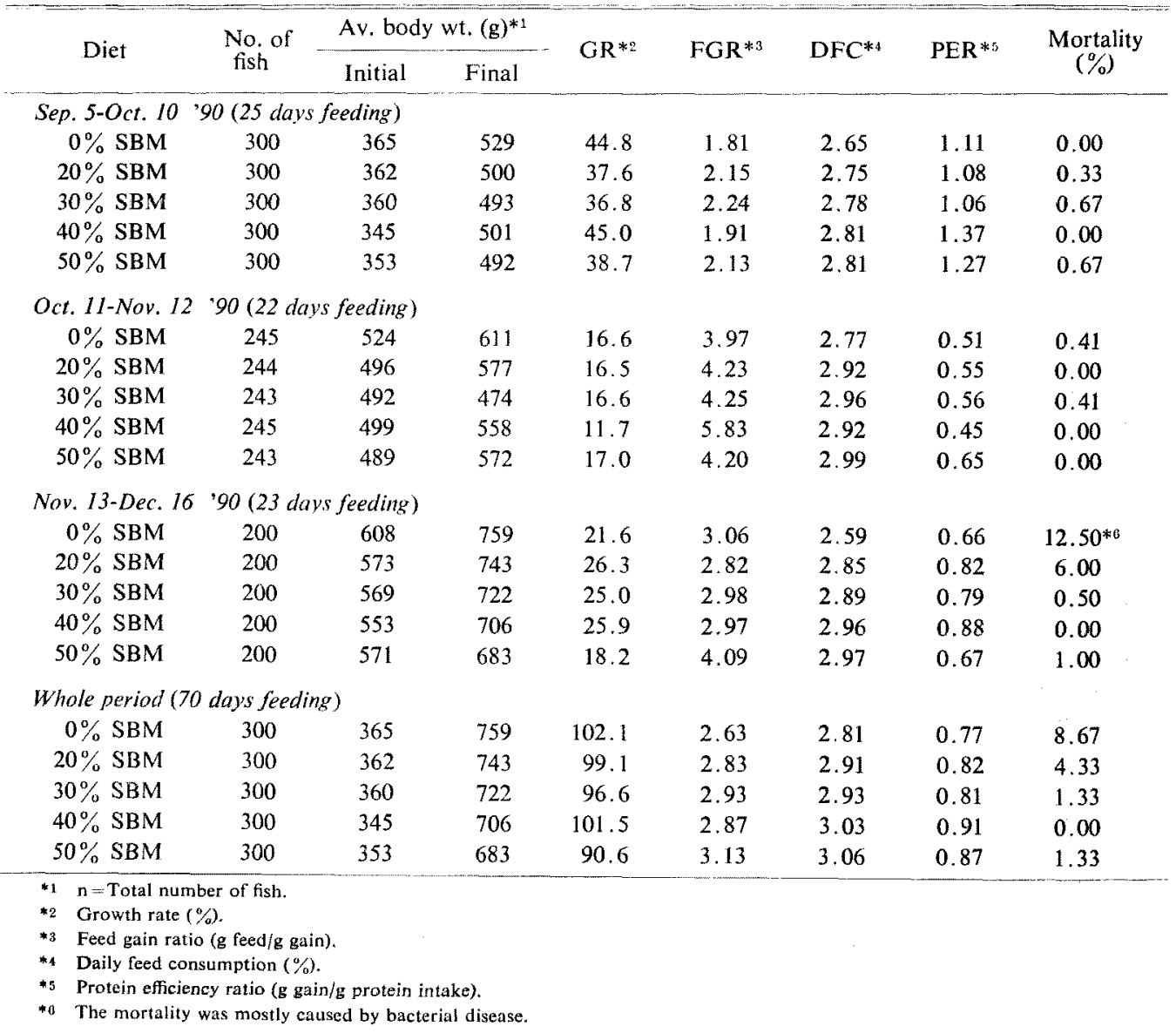


lowtail. Diet 6 contained $25 \%$ SBM and $15 \%$ corn gluten meal (CGM), the fish meal replacement level being the same as in diet 4 with $40 \%$ SBM. Replacement of fish meal with a similar combination of SBM and CGM has recently shown feed performances better than the control fish meal diet in rainbow trout. Diet 6 was used in Expt. II. Supplemental lipid levels were increased to $17-22 \%$ in diets $2-6$ in order to elevate the digestible energy (DE) levels. These experimental diets were all extruded by twin extruder to soft-dry pellets of $7 \mathrm{~mm}$ diameter as described in the previous paper ${ }^{33}$ and kept in a cold storage room during the experimental period. The diets were crushed and sieved to a suitable size for juvenile yellowtail of $39.0 \mathrm{~g}$ in Expt. II.

The experimental diets were not formulated to be iso-nitrogenous or iso-caloric, thus the protein and energy contents reduced inversely to dietary SBM levels, as shown in Table 1 . The crude protein content was about $49 \%$ for both the control diets and was $36-43 \%$ for the SBM diets. The DE content of the control diet was $4.1 \mathrm{kcal} / \mathrm{g}$, which was reduced to 3.6 $\mathrm{kcal} / \mathrm{g}$ in the $50 \% \mathrm{SBM}$ diet. The DE content was calculated on the basis of the energy digestibility of the diets with 30,40 , and $50 \%$ SBM as determined in the former experiment.

The fatty acid composition of the experimental diets used in Expt. 1, analyzed by methods described previously, is shown in Table 2. There was no marked difference in the fatty acid profile in terms of $n-3$ highly unsaturated fatty acid (n-3 HUFA) levels.

\section{Determination of Hematological Characteristics}

Blood was sampled from the net-caged juvenile yellowtail (Expt. 1) on December 20th. Fish were starved for $24 \mathrm{~h}$ prior to blood taking. Fish were angled and then blood samples were obtained by cardiac puncture with heparinized syringes fitted with $18 \mathrm{G}$ needles. The blood samples were kept at $4^{\circ} \mathrm{C}$ and hematocrit values $(\mathrm{Ht})$ were determined within $2 \mathrm{~h}$ after taking the blood. Part of the blood was also centrifuged at 3,000 rpm for $10 \mathrm{~min}$ to obtain plasma samples. The hemochemical constituents examined were aspartate aminotransferase (GOT), alanin aminotransferase (GPT), alkaline phosphatase (Al-P), glucose (Glu), phospholipid (PL), total cholesterol (TCHO), urea nitrogen (BUN), and total protein (TP). The methods for determination of each parameter were all as described in a previous paper. ${ }^{12}$

\section{Rheological Properties and $K$ Value}

At the end of the feeding experiment (Expt. I) five fish were taken from each group and transferred to the Laboratory of Food Chemistry, Tokyo University of Fisheries, to measure and compare the rheological properties and $K$ value of muscle. Instantaneous elastic modulus, viscosity, rupture strength, and $\mathrm{K}$ value were all determined by the same methods as described previously. ${ }^{1,5}$ )

\section{Results and Discussion}

\section{Feed Performances}

Expt. I: Results of the feeding experiment during September to December in the net cages are shown in Table 3 and Fig. 1. Palatability or acceptability of the experimental diets was not influenced by the inclusion of SBM up to $50 \%$, as inferred from the daily feed consumption which was rather high in the SBM diets (Table 3). This increased level of feed consumption may partly be due to lower dietary protein levels in

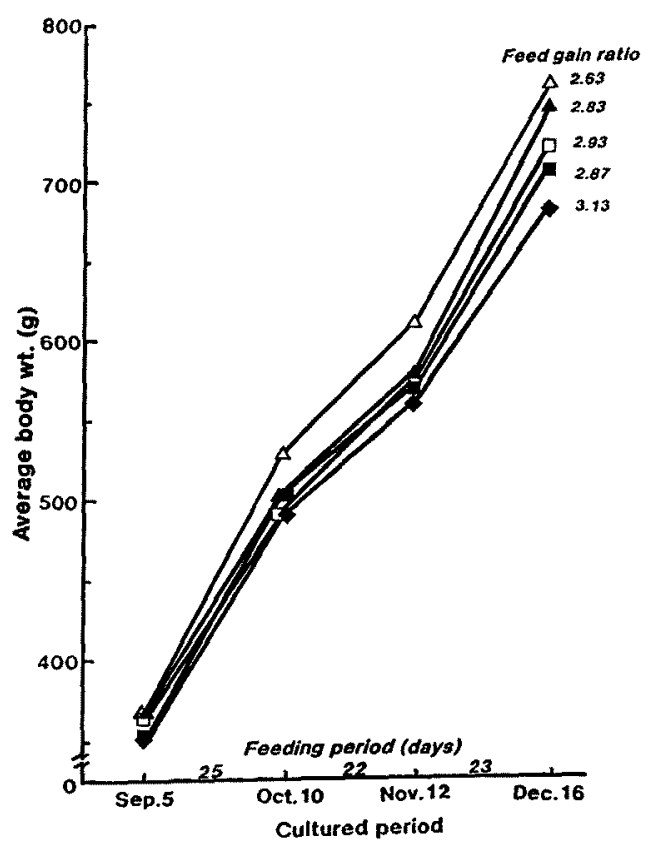

Fig. 1. Growth curves of adult yellowtail fed on experimental soft-dry pellets containing $0(\triangle-$ $\triangle), 20(\Delta-\Delta), 30(\square-\square), 40(\mathbf{\square}-\mathbf{D})$, and $50 \%$ $(-)$ soybean meal in $3 \times 3 \times 3 \mathrm{~m}$ net cages, respectively. (Expt. I) 

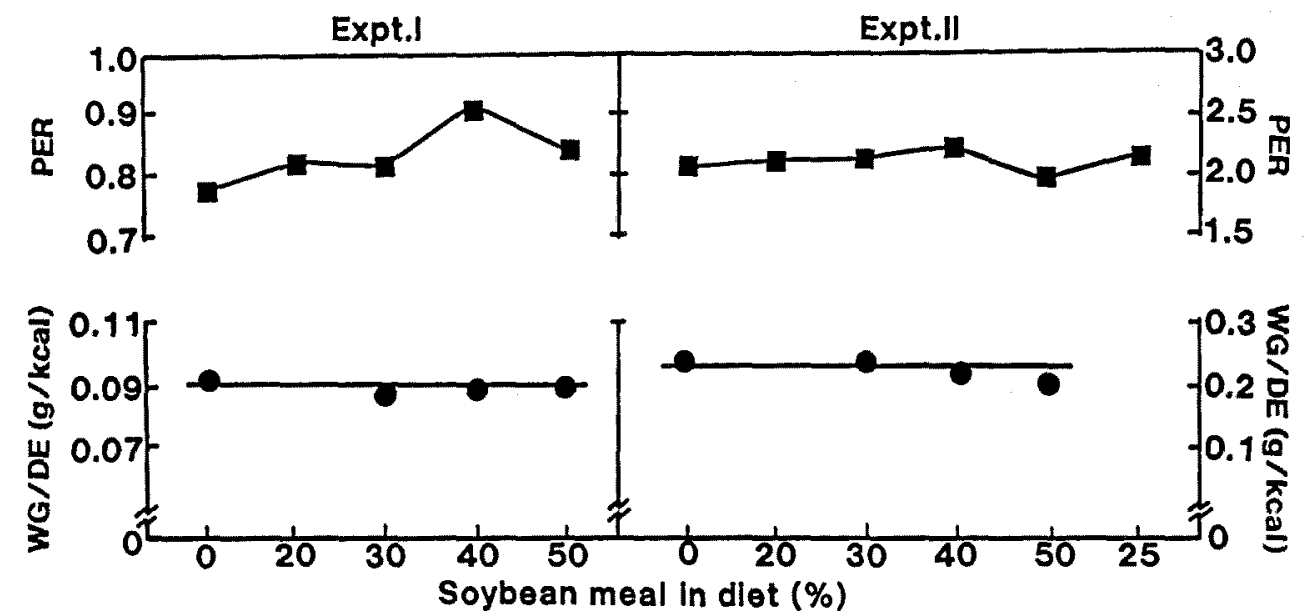

Fig. 2. The body weight gain per protein intake (PER) and per digestible energy intake (WG/DE) in adult and juvenile yellowtail. (Expts. I and II)

Table 4. Results of juvenile yellowtail fed on soft-dry pellets containing different levels of soybean meal (SBM) in $500 /$ tanks*1 (Expt. II)

\begin{tabular}{|c|c|c|c|c|c|c|c|c|}
\hline \multirow{2}{*}{ Diet } & \multirow{2}{*}{$\begin{array}{l}\text { No. of } \\
\text { fish }\end{array}$} & \multicolumn{2}{|c|}{ Av. body wt. (g)*2 } & \multirow{2}{*}{$\mathrm{GR}^{* 3}$} & \multirow{2}{*}{ FGR $^{* 3}$} & \multirow{2}{*}{$\mathrm{DFC}^{* 3}$} & \multirow{2}{*}{ PER*3 } & \multirow{2}{*}{$\begin{array}{l}\text { Mortality } \\
\text { (fish) }\end{array}$} \\
\hline & & Initial & Final & & & & & \\
\hline \multicolumn{9}{|c|}{ Whoie period: Jul. I4-Aug. 25 '90 (36 days feeding) } \\
\hline $0 \% \mathrm{SBM}$ & 25 & $39.1 \pm 2.9$ & $179.0 \pm 40.1^{8}$ & 357 & 1.00 & 3.57 & 2.02 & 1 \\
\hline $20 \% \mathrm{SBM}$ & 25 & $39.0 \pm 2.7$ & $176.8 \pm 23.9^{n}$ & 354 & 1.04 & 3.68 & 2.11 & 2 \\
\hline $30 \% \mathrm{SBM}$ & 25 & $39.2 \pm 2.8$ & $175.3 \pm 48.5^{a}$ & 347 & 1.13 & 3.97 & 2.13 & 0 \\
\hline $40 \% \mathrm{SBM}$ & 25 & $39.1 \pm 2.8$ & $153.3 \pm 27.8^{b}$ & 292 & 1.20 & 3.96 & 2.17 & 0 \\
\hline $50 \% \mathrm{SBM}$ & 25 & $39.0 \pm 3.3$ & $143.5 \pm 20.1^{b}$ & 268 & 1.33 & 4.23 & 1.96 & 1 \\
\hline $25 \%$ SBM & 25 & $39.2 \pm 3.2$ & $160.6 \pm 33.5^{\mathrm{ab}}$ & 309 & 1.07 & 3.62 & 2.15 & 2 \\
\hline
\end{tabular}

the SBM diets. Growth and feed gain ratio were highest in fish fed on the control diet without SBM (diet 1). There was no marked difference in growth among the groups fed on the SBM diets until November, but thereafter the growth dropped in proportion to the increasing dietary SBM levels. Growth performances of the SBMfed groups and their differences from the control showed almost the same tendency as noted in the former experiment. Growth and feed gain ratio reduced on elevation of SBM levels in diet, which might be due to the reduced levels of protein and energy in the SBM diets, as shown in Table 1. This was also supported by the result shown in Fig. 2, i.e. that the weight gain per DE or protein intake did not differ greatly among the experimental groups. This suggests that growth improved on elevation of dietary DE and protein contents. The values for protein efficiency ratio
(PER) were somewhat higher in the SBM diets due to lower dietary protein levels. However, the values were markedly lower than those in the polycarbonate tanks, probably due to greater feed loss in the net cages. Both growth and feed gain ratio were significantly lower in all the groups than those in the former experiment. They were especially low during the 22 days feeding from October 11 th to November 12 th, though the reason for this was unknown.

The present feed performance, in corroboration with our previous study, suggests that SBM could be included up to $30 \%$ as a protein source in practical soft-dry pellets for yellowtail. However, it may be difficult to improve the nutritional quality of the $50 \% \mathrm{SBM}$ diet to a level comparable to the control fish meal diet because of a fairly high proportion of undigestible part derived from $50 \% \mathrm{SBM}$ inclusion. 


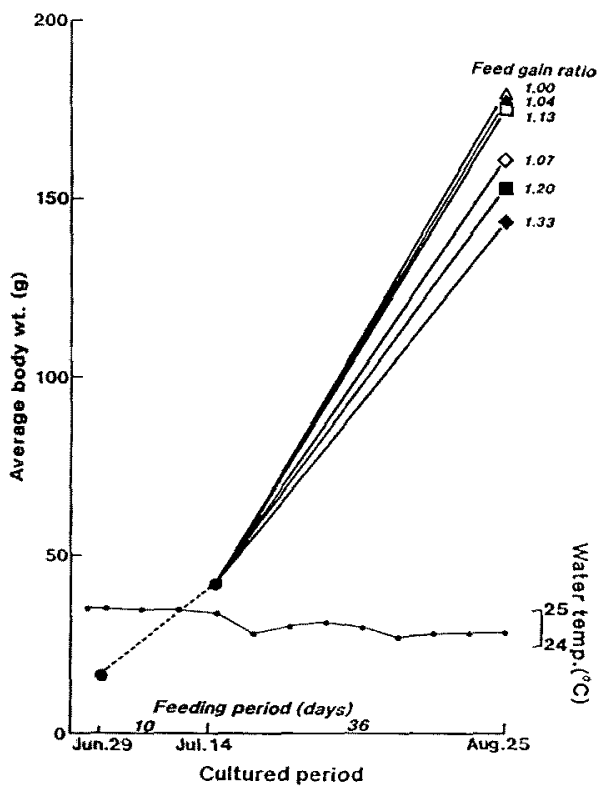

Fig. 3. Growth curves of juvenile yellowtail fed on a commercial soft-dry pellet (--.) during preliminary feeding and on experimental softdry pellets containing $0(\triangle-\Delta), 20(\Delta-\Delta), 30$ $(\square-\square), 40(\square-\square), 50 \%(\bullet-\bullet)$, soybean meal, and $25 \%$ soybean meal with $15 \%$ corn gluten meal $(\circlearrowleft-\infty)$ in $500 /$ tanks, respectively. (Expt. II)

Expt. II: Results of feeding in the land-based rearing tanks are shown in Table 4 and Fig. 3 . Growth and feed gain ratio showed almost the same tendency as those observed in Expt. I and were inversely related to dietary SBM levels, although there were no marked differences between fish fed on the high protein-medium energy control diet and the experimental diet with 20 or $30 \%$ SBM. As remarked in Expt. I, the reduced growth in fish fed 40 and $50 \%$ SBM might be improved on elevation of dietary protein and energy levels as evidenced in the weight gain per DE or protein intake (Fig. 2). Both the values were somewhat higher than those in Expt. I due to negligible feed loss in the $500 \mathrm{l}$ tanks. On the other hand, the diet containing $25 \%$ SBM and $15 \%$ CGM showed better feed performances than the diet with $40 \%$ SBM, suggesting the availability of CGM as a protein source in combination with SBM. The fish fed on the diet with CGM also had a clear yellowish pigmentation in the lateral line, indicating that lutein in the CGM was converted to tunaxanthin, the ingredient thereby proving to be of cosmetic importance.

The feed gain ratio was markedly higher than that obtained in the net cages (Expt. I) and was $1.00,1.04$, and 1.07 for the control, the $20 \%$ SBM, and the CGM groups, respectively. Even the $50 \%$ SBM diet recorded a ratio of 1.33 . The explanations offered are the unregistered feed loss and the increased energy expenditure of the larger fish in the net cage experiment. ${ }^{3)}$ Daily feed consumption was proportional to dietary SBM levels in terms of reduced protein and energy levels.

\section{Proximate Composition of Muscle and Carcass}

The protein, lipid, and ash contents of the dorsal and ventral muscles are shown in Table 5, while those of the carcass determined in October and December in Expt. I are shown in Table 6.

Expt. I: The protein and ash contents were slightly higher in the dorsal muscle than in the ventral muscle, while the lipid content was higher in the latter. The protein content did not differ greatly among the dorsal muscles from each lot, but was slightly lower in the ventral muscle from the 40 and $50 \%$ SBM groups. The lipid content was also slightly higher in the ventral muscle from the SBM diet-fed groups. The ash content was slightly higher in both the muscles of fish fed on the SBM diets.

The protein content of the carcass did not differ greatly among the groups and decreased slightly from Octover to December. The lipid content was higher in fish fed on the SBM diets rich in lipid and increased during October to December in accordance with the growth of fish. The ash content in December was slightly higher in the $50 \%$ SBM group.

Expt. II: The patterns of proximate composition were very similar to Expt. I. The lipid content was higher in the ventral muscle, but the difference between the dorsal and ventral muscles was not so marked as in Expt. $I$, as the fish in this case was smaller.

\section{Lipid Content of Liver and Hepatosomatic Index}

The lipid content of the liver and hepatosomatic index from the juvenile yellowtail in Expt. II are shown in Table 7.

The lipid content of liver increased proportionally to the dietary SBM and lipid levels. Fish fed on the diet containing $25 \%$ SBM and $15 \%$ CGM fell in the mid-range between the 30 and $40 \%$ SBM groups in terms of lipid content in the 
Table 5. Proximate composition of the dorsal and ventral muscles of yellowtail fed on soft-dry pellets containing different levels of soybean meal (SBM)

\begin{tabular}{|c|c|c|c|c|c|c|}
\hline \multirow[t]{2}{*}{ Diet } & \multicolumn{2}{|c|}{$\begin{array}{l}\text { Crude protein } \\
\text { Muscle }\end{array}$} & \multicolumn{2}{|c|}{$\begin{array}{c}\text { Crude lipid } \\
\text { Muscle } \\
\end{array}$} & \multicolumn{2}{|c|}{$\begin{array}{l}\text { Crude ash } \\
\text { Muscle }\end{array}$} \\
\hline & Dorsal & Ventral & Dorsal & Ventral & Dorsal & Ventral \\
\hline \multicolumn{7}{|c|}{ Expt.I } \\
\hline \multicolumn{7}{|c|}{ Final: Dec. 16 '90 $(n=5)$} \\
\hline $0 \% \mathrm{SBM}$ & 23.3 & 22.6 & 6.7 & 10.3 & 1.7 & 1.5 \\
\hline $20 \% \mathrm{SBM}$ & 23.6 & 22.2 & 6.2 & 12.0 & 1.8 & 1.5 \\
\hline $30 \% \mathrm{SBM}$ & 23.8 & 22.3 & 7.1 & 12.8 & 1.8 & 1.7 \\
\hline $40 \% \mathrm{SBM}$ & 23.3 & 21.5 & 6.6 & 12.2 & 1.8 & 1.6 \\
\hline $50 \% \mathrm{SBM}$ & 22.8 & 21.7 & 7.0 & 12.1 & 1.9 & 1.6 \\
\hline \multicolumn{7}{|c|}{ Expt. II } \\
\hline \multicolumn{7}{|c|}{ Initial: Jul. 14 ' $^{\prime} 90(n=6)$} \\
\hline $\mathrm{CM} \operatorname{diet}^{*}$ & 21.9 & 21.7 & 2.3 & 3.8 & 1.6 & 1.5 \\
\hline \multicolumn{7}{|c|}{ Final: Aug. 25 '90 $(n=3)$} \\
\hline $0 \% \mathrm{SBM}$ & 23.2 & 22.5 & 3.6 & 5.2 & 1.9 & 1.6 \\
\hline $20 \% \mathrm{SBM}$ & 22.6 & 22.3 & 4.0 & 5.2 & 1.8 & 1.7 \\
\hline $30 \% \mathrm{SBM}$ & 23.0 & 21.9 & 3.1 & 5.9 & 1.8 & 1.8 \\
\hline $40 \%$ SBM & 22.2 & 21.2 & 4.3 & 7.3 & 1.9 & 1.5 \\
\hline $50 \% \mathrm{SBM}$ & 21.8 & 21.0 & 3.8 & 6.8 & 1.7 & 1.7 \\
\hline $25 \% \mathrm{SBM}$ & 22.3 & 21.0 & 5.1 & 8.8 & 1.9 & 2.0 \\
\hline
\end{tabular}

* A commercial soft-dry pellet for yellowtail ( $0 \%$ SBM).

Table 6. Proximate composition of the carcass of the adult yellowtail fed on soft-dry pellets containing different levels of soybean meal (SBM) in $3 \times 3 \times 3 \mathrm{~m}$ net cages (Expt. I)

\begin{tabular}{lccc}
\hline Diet & $\begin{array}{c}\text { Crude } \\
\text { protein }\end{array}$ & $\begin{array}{c}\text { Crude } \\
\text { lipid }\end{array}$ & $\begin{array}{c}\text { Crude } \\
\text { ash }\end{array}$ \\
\hline Initial: Sep. 4 & $90(n=3)$ & & \\
CM diet* & 20.5 & 10.1 & 2.6 \\
Oct. 11 '90 $(n=5)$ & & & \\
$0 \%$ SBM & 21.3 & 7.4 & - \\
$20 \%$ SBM & 21.8 & 7.2 & - \\
$30 \%$ SBM & 21.4 & 10.8 & - \\
$40 \%$ SBM & 20.4 & 9.2 & - \\
$50 \%$ SBM & 20.8 & 8.6 & - \\
Final: Dec. I6 '90 $(n=3)$ & & \\
$0 \%$ SBM & 20.6 & 10.4 & 2.6 \\
$20 \%$ SBM & 20.0 & 12.1 & 2.5 \\
$30 \%$ SBM & 19.9 & 13.5 & 2.7 \\
$40 \%$ SBM & 20.3 & 11.9 & 2.7 \\
$50 \%$ SBM & 19.7 & 13.4 & 2.9 \\
\hline See the footnote to Table 5. & & \\
\hline
\end{tabular}

diet.

The hepatosomatic index was also higher in the SBM diet groups, reflected by the lipid content in the liver.

\section{Hematological Characteristics}

The results of hemochemical assessments in
Table 7. Crude lipid content of the liver and hepatosomatic index of the juvenile yellowtail fed on soft-dry pellets containing different levels of soybean meal (SBM) in $500 l$ tanks (Expt. II)

\begin{tabular}{|c|c|c|}
\hline Diet & $\begin{array}{l}\text { Crude } \\
\text { lipid }\end{array}$ & $\begin{array}{c}\text { Hepatosomatic } \\
\text { idex*1 }\end{array}$ \\
\hline \multicolumn{3}{|c|}{ Initial: Jul. 14 '90 $(n=3)$} \\
\hline $\mathrm{CM} \operatorname{diet}^{* 2}$ & 5.5 & $1.4 \pm 0.30^{\mathrm{b}}$ \\
\hline \multicolumn{3}{|c|}{ Final: Aug. 25 '90 $(n=3)$} \\
\hline $0 \% \mathrm{SBM}$ & 4.9 & $1.2 \pm 0.14^{\mathrm{ab}}$ \\
\hline $20 \% \mathrm{SBM}$ & 7.9 & $1.0 \pm 0.25^{a}$ \\
\hline $30 \%$ SBM & 7.6 & $1.3 \pm 0.06^{\mathrm{ab}}$ \\
\hline $40 \% \mathrm{SBM}$ & 12.3 & $1.4 \pm 0.19^{\mathrm{b}}$ \\
\hline $50 \% \mathrm{SBM}$ & 14.7 & $1.4 \pm 0.25^{\mathrm{b}}$ \\
\hline $25 \% \mathrm{SBM}$ & 11.0 & $1.4 \pm 0.31^{\mathrm{b}}$ \\
\hline \multicolumn{3}{|c|}{$\begin{array}{l}\text { Mean IS.D. }(\mathrm{n}=3) \text { and figures in columns with differen } \\
\text { superscripts are significantly different from each othe } \\
(p<0.05) \text {, calculated by Duncan's new multiple-range test. } \\
\text { See the footnote to Table } 5 \text {. }\end{array}$} \\
\hline
\end{tabular}

fish reared in the net cages (Expt. I) are illustrated in Fig. 4. The health condition of fish fed on the control diet was not as good as that of the 20 and $30 \%$ SBM diets, but better than that of the 40 and $50 \%$ SBM diets. However, the difference between the groups was very little. Indepth examination indicated an increase of GOT and GPT in a few fish from the 40 or $50 \% \mathrm{SBM}$ groups, the significance of which could not be 


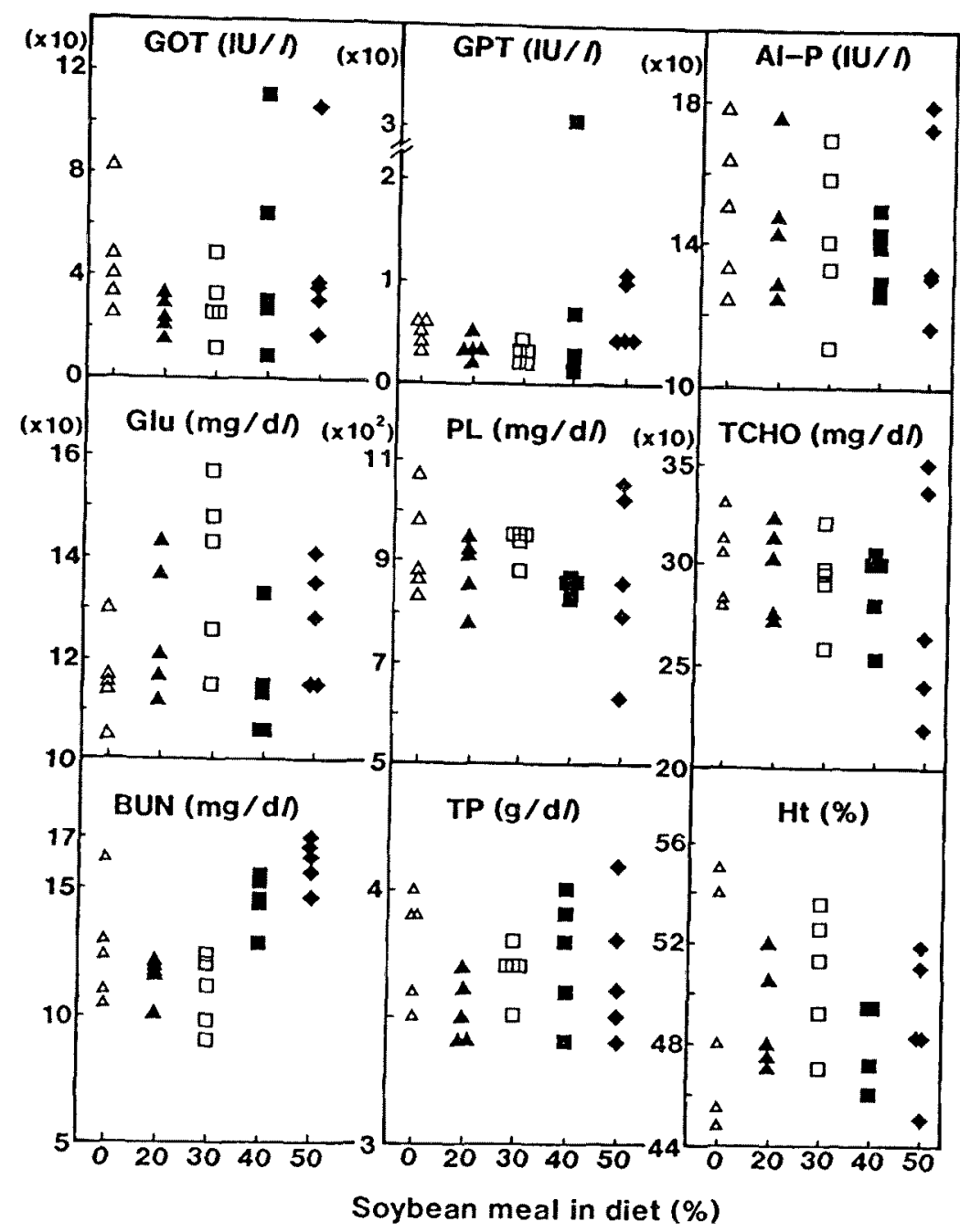

Fig. 4. Results of hemochemical assessments in adult yellowtail fed on experimental soft-dry pellets containing $0(\Delta), 20(\Delta), 30(\square), 40(\square)$, and $50 \%(\diamond)$ soybean meal in $3 \times 3 \times 3 \mathrm{~m}$ net cages, respectively. (Expt. $I)$

clarified as the fish in all the groups were apparently normal at sampling. The levels of PL and TCHO were also scattered in the $50 \% \mathrm{SBM}$ group. BUN measurements increased in the $40 \%$ SBM group and more distinctly in the $50 \% \mathrm{SBM}$ group. It was also not clear whether these fluctuations in blood parameters were related to dietary inclusion of high levels of SBM or lipids. Nevertheless, it seems plausible that SBM could be included as a protein source for up to $30 \%$ in place of fish meal (substitution of about $55 \%$ fish meal) in soft-dry pellets for yellowtail, without any deterioration of hemochemical indices.

\section{Rheological Properties}

The rheological parameters of the muscles from fish fed on the test diets in the net cages (Expt. I) are shown in Table 8.

There were marked differences in instantaneous elastic modulus $\left(E_{0}\right)$ and viscosity $\left(\eta_{1}\right)$ between the muscle of fish fed on the diets with 0 or $20 \%$ SBM and the diets with 30,40 , or $50 \%$ SBM. The latter groups have higher values of $E_{0}$ and $\eta_{1}$ than the former groups, although the mean values were largely scattered, suggesting inhomogeneity in the structure of the meat sample. The low $E_{0}$ and $\eta_{1}$ values of fish fed on the control or $20 \%$ SBM diets reflect their tenderness compared to 
Table 8. Rheological parameters of muscles from the adult yellowtail fed on soft-dry pellets containing different levels of soybean meal (SBM) in $3 \times 3 \times 3$ m net cages* (Expt. $)$

\begin{tabular}{ccclc}
\hline Diet & $\begin{array}{c}\text { Instantaneous } \\
\text { elastic modulus }\end{array}$ & Viscosity & $\begin{array}{c}\text { Rupture } \\
\text { strength }\end{array}$ & $K$ value \\
\hline $0 \%$ SBM & $\begin{array}{c}E_{0} \times 10^{-5} \\
\left(\text { dyn } / \mathrm{cm}^{2}\right)\end{array}$ & $\begin{array}{c}\eta_{1} \times 10^{-7} \\
(\text { poise })\end{array}$ & $\begin{array}{c}R \times 10^{-4} \\
(\mathrm{dyn} / \mathrm{cm})\end{array}$ & $(\%)$ \\
\hline $20 \% \mathrm{SBM}$ & $10.8 \pm 3.5$ & $22.0 \pm 6.8$ & $4.1 \pm 0.9$ & $4.6 \pm 0.5$ \\
$30 \% \mathrm{SBM}$ & $12.2 \pm 3.1$ & $23.5 \pm 1.2$ & $4.9 \pm 1.1$ & $4.8 \pm 1.5$ \\
$40 \% \mathrm{SBM}$ & $24.4 \pm 3.2$ & $46.0 \pm 7.0$ & $4.0 \pm 0.9$ & $5.6 \pm 0.9$ \\
$50 \% \mathrm{SBM}$ & $25.5 \pm 15.4$ & $45.7 \pm 29.4$ & $4.9 \pm 0.7$ & $13.0 \pm 0.6$ \\
\hline
\end{tabular}

* Means \pm S.D. $(n=5)$.

other groups. However, the rupture strength (R) was almost the same in all groups, suggesting that the surfaces of the samples were not so different from each other. The $\mathrm{K}$ values of samples from the 40 and $50 \%$ SBM groups were higher than those from other groups.

In conclusion, there was no significant effect of dietary SBM levels of up to $30 \%$ on the flesh quality of yellowtail, as already observed in the previous experiment. ${ }^{1}$ )

\section{References}

1) T. Watanabe, V. Viyakarn, H. Kimura, T. Ogawa, N. Okamoto, and N. Iso: Utilization of soybean meal as a protein source in a newly developed soft-dry pellet for yellowtait. Nippon Suisan Gakkaishi, 58, 1761-1773 (1992).

2) T. Watanabe and J. Pongmaneerat: Quality evaluation of some animal protein sources for rainbow trout Oncorhynchus mykiss. Nippon Suisan Gakkaishi, 57, 495-501 (1991).

3) T. Watanabe, H. Sakamoto, M. Abiru, and J. Yamasbita: Development of a new type of dry pellet for yellowtail. Nippon Suisan Gakkaishi, 57, 891-897 (1991).

4) T. Takeuchi, M. Toyota, and T. Watanabe: Comparison of lipid and n-3 highly unsaturated fatty acid incorporations between Artemia enriched with various types of oil by a direct method. Nippon Suisan Gakkaishi, 58, 277-281 (1992).

5) N. Iso, H. Mizuno, T. Saito, F. Ohzeki, and C.-Y. Lin: Studies on the rheological properties of heated carp meats. Nippon Suisan Gakkaishi, 50, 349-353 (1984). 